\title{
EYE-TRACKING ANALYSIS OF LEAFY VEGETABLES
}

\author{
ILdikó FruZsina Boros ${ }^{1,2}$, LÁSZló Sipos ${ }^{1}$, ATtILA GERE ${ }^{1}$ \\ ${ }^{1}$ Szent István University, Faculty of Food Science, Department of Postharvest and Sensory \\ Evaluation, 29-43 Villányi Street, H-1118 Budapest, Hungary \\ ${ }^{2}$ Szent István University, Faculty of Horticultural Science, Department of Vegetable and \\ Mushroom Growing, 29-43 Villányi Street, H-1118 Budapest, Hungary \\ boros.ildiko.fruzsina@kertk.szie.hu
}

\begin{abstract}
There is a great supply of leafy vegetables on the market; hence capturing consumer's attention (and decision) is critically important. Several scientific publications deal with consumer choices and the newest technology to capture consumer attention is eye-tracking. Eye-trackers are commonly used in Western Europe and Asia also, where it is an important and widely-used tool during product developments and the creation of marketing strategies. In Hungary, there are only a few publications about eye-tracking applications in vegetable growing and food industry. In our research, photographs about sorrel, lamb lettuce, spinach, leaf lettuce and dandelion leafs were analysed by eye-tracking technology and the eye movements of the participants during their decision making process of leafy vegetables were captured and evaluated. The eye-tracking analyses were carried out in the Sensory Laboratory of the Faculty of Food Sciences of Szent István University, using a Tobii X2-60 eye-tracker and Tobii Studio (version 3.0.5, Tobii Technology AB, Sweden) software. We aimed to answer the following research questions: Are there any connections between the eye movements of participants and their decisions? What amount of visual attention can be registered during the decision making process? Furthermore, the following metrics were measured and evaluated: fixation durations on the leafy vegetables, number of returns to products, pathways of visual attention, time until the final decision making and motivation of their final decisions. Measurement of the subconscious consumer decision making processes is way easier using eye-trackers compared to the traditional questionnaire-based methods, because it is hard or impossible to control our eye movements. Eye-tracking can be used successfully for understanding the expectations and decisions of the consumers.
\end{abstract}

Keywords: eye-tracking, leafy vegetables, value-based segmentation; eye movements

\section{INTRODUCTION}

Acceptance of minimally processed vegetables has been increased in the last few years (ZHOU ET AL., 2004). Wide range of consumers are looking for that products, primarily those who have family with young children and higher education (RAGAERT ET AL., 2004). Psychologic factors also play role in the gazing behaviour not just gender or sociodemographic factors (ARES ET AL., 2014). To understand consumer's gazing behaviour, itis also valuable to analyse the consumer's personal values. For identification of people's behaviour and motives, marketers typically use the so-called value based segmentation technique (VERAIN ET AL., 2016). Appearance is one of the key factors in food quality. Visual attention plays an important role in food choices (GERE ET AL., 2016), because the first impression about the food and their quality takes through visual appearance, which very often is the only attribute that could help in the decision making during the purchase (CARDEllo, 1998; KeAst, 2010). Attributes related to appearance are important for consumers but these are the most susceptible to objective measures (TZIA ET AL., 2016).

Eye-tracking is widely used for capturing the eye movements of participants while they are completing different tasks (e.g.: choice tasks, free viewing tasks, etc.). Several eyetracking parameters could be measured that can be used to characterize the gazing pattern of the individuals (HOLMQVIST ET AL., 2011). 


\section{MATERIAL AND METHOD}

This study was a slice of a bigger experiment work, and six alternatives were presented to the participants. Eye-tracking tests were performed in the Sensory Laboratory of the Faculty of Food Science of Szent István University, based on previous eye-tracking studies (GERE, 2016). For the recording and processing of the eye movement data of participants, a Tobii X2-60 static eye-tracker and the Tobii Studio (version 3.0.5, Tobii Technology AB, Sweden) data processing software were used. Images ensured the visual stimuli on a monitor with a 1280x1024 pixel resolution. Participants of the eye-tracking study were recruited from the Buda Campus of Szent István University. Participants were seated in front of a monitor connected to the eye-tracker, meanwhile their eyes were 60 to $65 \mathrm{~cm}$ from the monitor. They were asked to place their dominant hand on the mouse and not to move their heads and their positions. Calibrations were carried out before each test, then after the successful calibration, a text containing instructions related to the test appeared on the monitor, in which the process of the test was described in detail. Between the images, there was a black "+" sign, the so-called fixation cross, on the centre of the monitor. The purpose of the fixation cross was to standardize the starting point of attention. This was showed for $3 \mathrm{sec}$ and followed by selection tasks. After reaching the decision, the participant clicked on the left mouse button to bring up the previously invisible mouse pointer on the display, and then they could click on the selected product. 163 people participated in the study and data recording was successful for everyone, but only 140 results were perfectly fitted for the picture that contains six component, these were included in the data analysis.

During the evaluation of the eye-tracking measurement results, work was based on the following definitions (GERE ET AL., 2016): 1. Fixation duration: the average length of fixations on a given area of interest (AoI). 2. Fixation counts: the number of fixations for a specific product that shows how many times the given product was viewed by the participant. 3. Dwell duration: the average length of glimpses at different product images during gaze wandering between two fixations, when no information is absorbed. 4. Dwell count: the total number of visits for a given area of interest (AoI).

Before the test, participants were asked to rate importance of the values listed in the first column of Table 1. The labels of the applied 5-point scale were the following: not important at all, less important, moderately important, important, really important.

In this study cluster analysis was used for characterisation and margin of homogenous clusters, that method makes relative homogenous clusters (MALHOTRA, 2005). One advantage is for cluster analysis is that the thinking of the researcher could not affects the segmentation, because method uses distance matrix between data points. During the cluster analysis, hierarchical analysis was done using Euclidean distance and Ward's agglomeration method. Due to the hierarchical nature of the method, the cases were agglomerated step-by-step. The benefit of hierarchical methods is that they try to make almost equal sized clusters and a dendrogram helps to visualize the agglomeration schedule and the structure of the created clusters. XL-Stat software (Addinsoft, 28 West 27th Street, Suite 503, New York, NY 10001, USA) was used for the analyses.

\section{RESULTS}

Figure 1 shows a heat map of the fixation durations (from green to red colour means the duration of fixation and red corresponds to the most watched product) of all participants. It shows that leaf lettuce received the most visual attention, after that come rocket salad, and 
sorrel. The green spot on the centre of the picture, refers to the previously watched „,+" sign.
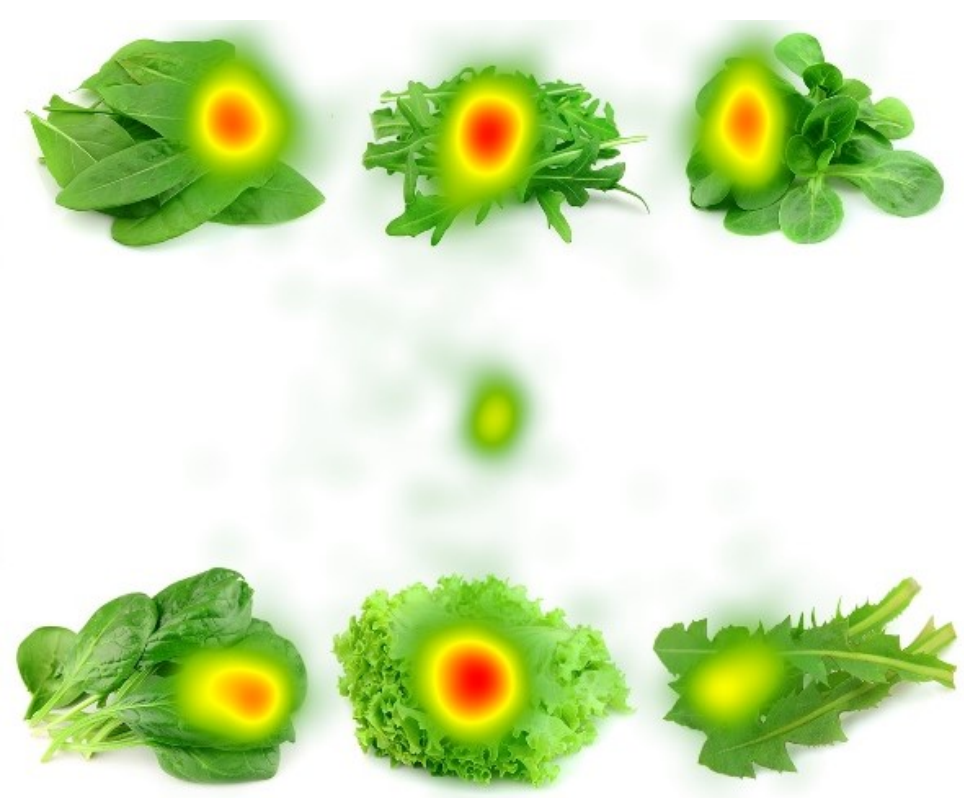

Figure 1. Heat map of the photographs about sorrel, rocket salad, lamb lettuce, spinach, leaf lettuce and dandelion leaves

Based on the value structure results of homogenous groups (clusters), were classified by:

- characterisation of clusters based on their values,

- characterisation of clusters based on eye movement parameters,

- characterisation of clusters based on duration of decision making.

Based on the structures of the values, results with one exception (enjoyable life), every attribute based on eye movement parameters showed significant differences $(\alpha=0.05)$ according to the applied Kruskal-Wallis test. Based on the results, participants were sorted into 4 different clusters based on their values (Ward's method, Euclidean distance). Each cluster was characterised by their mean, dispersion and Dunn's pairwise comparison with Bonferroni correction, which gives letter markings for homogenous and heterogeneous groups. That gives an opportunity to analyse clusters about significant differences between parameters of each cluster. On the top of Table 1 the values of attributes are showed, meanwhile below those values are showed parameters about eye movements.

In the first cluster the 'conservative self-realized' individuals are located, because they live a family centred life with conservative custom values, meanwhile true friendship, selfrealization, personal and financial security and education plays also important roles in their lifestyle. The least important attribute for them is alternative/not traditional living style. They were the most precious, because the counts of fixations and dwells, and duration of fixations and dwells were also the highest and the longest during the tests.

Members of second cluster are the 'life enjoyed independents', who prefer the following values the most: true friendship, personal and financial security, enjoyable life, personal freedom/ independence, although value of traditions was the least important for them. The eye movement parameters showed, that they fixated shorter and more often on the pictures. In the third cluster we identified the 'financial-social-educated' participants. Most important values were for them: personal and financial security, true friendship and education. Interesting that every attributes got higher importance than 'moderately important' value. Eye movement parameters showed that dwell counts were moderated 
compared to other clusters, therefore fixation count and fixation and dwell durations were really low and short such as in case of the fourth cluster.

The fourth cluster contained 'immediate environment centred indifferentists' who actually just interested in family life, true friendship and enjoyable life and other attributes are moderately important for them. Their eye movement parameters tell that they needed the shortest and lowest fixations and dwells (Table 1). Based on these, they watched the pictures sloppily.

Table 1. Characterization of clusters by values (the first five values of each cluster are highlighted (darkest is the most important)

\begin{tabular}{|c|c|c|c|c|c|}
\hline Attributes & Cluster1 & Cluster2 & Cluster3 & Cluster4 & $\begin{array}{l}\text { Kruskal } \\
\text {-Wallis }\end{array}$ \\
\hline True friendship & $4.77 \pm 0.42 b$ & $4.78 \pm 0.52 b$ & $4.80 \pm 0.40 \mathrm{~b}$ & $4.18 \pm 0.65 \mathrm{a}$ & 0.0003 \\
\hline Family life & $4.70 \pm 0.53 b$ & $4.36 \pm 0.62 \mathrm{a}$ & $4.69 \pm 0.61 b$ & $4.56 \pm 0.51 \mathrm{ab}$ & 0.0136 \\
\hline $\begin{array}{l}\text { Personal and } \\
\text { financial security }\end{array}$ & $4.40 \pm 0.62 b$ & $4.51 \pm 0.55 b$ & $4.80 \pm 0.40 \mathrm{c}$ & $3.68 \pm 0.94 \mathrm{a}$ & $<0.0001$ \\
\hline Enjoyable life & $4.29 \pm 0.73 \mathrm{ab}$ & $4.39 \pm 0.62 \mathrm{ab}$ & $4.50 \pm 0.64 \mathrm{~b}$ & $4.06 \pm 0.68 \mathrm{a}$ & 0.1969 \\
\hline Self-realization & $4.66 \pm 0.57 \mathrm{c}$ & $4.34 \pm 0.61 \mathrm{~b}$ & $4.57 \pm 0.64 b c$ & $3.62 \pm 0.61 \mathrm{a}$ & $<0.0001$ \\
\hline Social origin & $4.45 \pm 0.62 b c$ & $4.12 \pm 0.84 \mathrm{ab}$ & $4.65 \pm 0.56 c$ & $3.75 \pm 1.23 \mathrm{a}$ & 0.0059 \\
\hline $\begin{array}{l}\text { Personal freedom/ } \\
\text { independence }\end{array}$ & $3.98 \pm 0.81 \mathrm{a}$ & $4.39 \pm 0.58 b$ & $4.69 \pm 0.54 b$ & $3.50 \pm 1.09 \mathrm{a}$ & $<0.0001$ \\
\hline Education & $4.12 \pm 0.73 b$ & $4.29 \pm 0.71 b$ & $4.73 \pm 0.45 c$ & $3.31 \pm 0.70 \mathrm{a}$ & $<0.0001$ \\
\hline Comfortable life & $3.61 \pm 0.70 \mathrm{a}$ & $4.21 \pm 0.65 b$ & $4.42 \pm 0.70 \mathrm{~b}$ & $3.56 \pm 1.03 \mathrm{a}$ & $<0.0001$ \\
\hline $\begin{array}{l}\text { Having a lot of } \\
\text { free time }\end{array}$ & $3.43 \pm 0.68 \mathrm{a}$ & $4.07 \pm 0.81 b c$ & $4.30 \pm 0.73 c$ & $3.81 \pm 0.75 b$ & $<0.0001$ \\
\hline $\begin{array}{l}\text { Health } \\
\text { consciousness }\end{array}$ & $4.01 \pm 0.61 b$ & $3.87 \pm 0.67 \mathrm{~b}$ & $4.46 \pm 0.58 \mathrm{c}$ & $3.25 \pm 0.57 \mathrm{a}$ & $<0.0001$ \\
\hline Good appearance & $3.75 \pm 0.73 b$ & $3.92 \pm 0.68 \mathrm{~b}$ & $4.38 \pm 0.63 c$ & $3.25 \pm 0.77 \mathrm{a}$ & $<0.0001$ \\
\hline Economical living & $3.31 \pm 0.80 \mathrm{a}$ & $3.75 \pm 0.88 \mathrm{~b}$ & $4.26 \pm 0.72 \mathrm{c}$ & $3.37 \pm 1.08 \mathrm{ab}$ & 0.0001 \\
\hline $\begin{array}{l}\text { Environment and } \\
\text { energy conscious } \\
\text { life }\end{array}$ & $3.77 \pm 0.65 b$ & $3.70 \pm 0.87 \mathrm{~b}$ & $4.38 \pm 0.57 \mathrm{c}$ & $2.81 \pm 0.65 \mathrm{a}$ & $<0.0001$ \\
\hline $\begin{array}{l}\text { High living } \\
\text { standard }\end{array}$ & $3.40 \pm 0.77 \mathrm{~b}$ & $3.92 \pm 0.84 \mathrm{c}$ & $4.15 \pm 0.78 \mathrm{c}$ & $2.75 \pm 0.68 \mathrm{a}$ & $<0.0001$ \\
\hline $\begin{array}{l}\text { Caring about } \\
\text { culture and arts }\end{array}$ & $3.77 \pm 0.73 b$ & $3.02 \pm 0.79 \mathrm{a}$ & $4.38 \pm 0.63 c$ & $2.93 \pm 0.68 \mathrm{a}$ & $<0.0001$ \\
\hline Social recognition & $3.49 \pm 0.86 \mathrm{~b}$ & $3.17 \pm 0.86 \mathrm{ab}$ & $4.19 \pm 0.84 c$ & $2.56 \pm 1.03 \mathrm{a}$ & $<0.0001$ \\
\hline $\begin{array}{l}\text { Working for the } \\
\text { community }\end{array}$ & $3.56 \pm 0.65 b$ & $3.14 \pm 0.85 \mathrm{a}$ & $3.92 \pm 0.74 \mathrm{~b}$ & $2.75 \pm 0.85 \mathrm{a}$ & $<0.0001$ \\
\hline Traditions & $3.38 \pm 0.79 b$ & $2.36 \pm 0.62 \mathrm{a}$ & $4.11 \pm 0.90 \mathrm{c}$ & $3.25 \pm 0.68 \mathrm{~b}$ & $<0.0001$ \\
\hline $\begin{array}{l}\text { Alternative/not } \\
\text { traditional living } \\
\text { style }\end{array}$ & $3.03 \pm 1.08 \mathrm{~b}$ & $2.51 \pm 1.02 \mathrm{a}$ & $3.15 \pm 1.28 \mathrm{~b}$ & $2.18 \pm 0.83 \mathrm{a}$ & 0.0028 \\
\hline Fixation duration & $5.37 \pm 2.30 \mathrm{~b}$ & $4.40 \pm 2.05 \mathrm{a}$ & $3.74 \pm 1.52 \mathrm{a}$ & $3.54 \pm 1.71 \mathrm{a}$ & 0,002 \\
\hline Dwell duration & $6.18 \pm 3.22 b$ & $5.08 \pm 2.43 \mathrm{ab}$ & $4.42 \pm 2.64 \mathrm{a}$ & $3.87 \pm 1.46 \mathrm{a}$ & $\mathbf{0 , 0 1 1 2}$ \\
\hline Fixation count & $21.85 \pm 4.15 b$ & $21.24 \pm 3.80 \mathrm{~b}$ & $15.11 \pm 2.95 \mathrm{a}$ & $17.26 \pm 3.46 \mathrm{a}$ & $<0.0001$ \\
\hline Dwell count & $14.73 \pm 3.81 \mathrm{c}$ & $13.53 \pm 4.13 b c$ & $12.53 \pm 2.84 \mathrm{ab}$ & $11.06 \pm 2.67 \mathrm{a}$ & $\mathbf{0 , 0 0 2 7}$ \\
\hline
\end{tabular}


Decision times of the clusters created based on the values were compared by Survival Analysis. The curves' show similar characteristics. First cluster 'conservative self-realized' needed the longest time to make the final decision, that cluster was significantly different $(\alpha=0.05)$ from the others.

Participants of third cluster, 'financial-social-educated' and the forth cluster 'immediate environment centred indifferentist' were the fastest decision makers. These two clusters were not significantly different.

Members of the second cluster, ('life enjoyed independents') made their decisions significantly faster compared to participants from the first cluster ('conservative selfrealized'); meanwhile they were slower than people in the fourth cluster ('immediate environment centred indifferentist') (Table 2, Figure 2).

TABLE 2. Cluster value segmentation (Test statistic showed in the upper-right halfmatrix, p-values showed in the lower-left half-matrix). Significant differences are marked with bold.

\begin{tabular}{|l|c|c|c|c|}
\hline & Cluster1 & Cluster2 & Cluster3 & Cluster4 \\
\hline Cluster1 & - & $\mathbf{2 . 4 5 9 5 2 4}$ & $\mathbf{3 . 3 1 3 6 9 1}$ & $\mathbf{3 . 7 2 7 0 8 4}$ \\
\hline Cluster2 & $\mathbf{0 . 0 1 3 9 1}$ & - & 1.756353 & $\mathbf{2 . 3 7 0 8 9 9}$ \\
\hline Cluster3 & $\mathbf{0 . 0 0 0 9 2}$ & 0.07903 & - & 0.660465 \\
\hline Cluster4 & $\mathbf{0 . 0 0 0 1 9}$ & $\mathbf{0 . 0 1 7 7 4}$ & 0.50896 & - \\
\hline
\end{tabular}

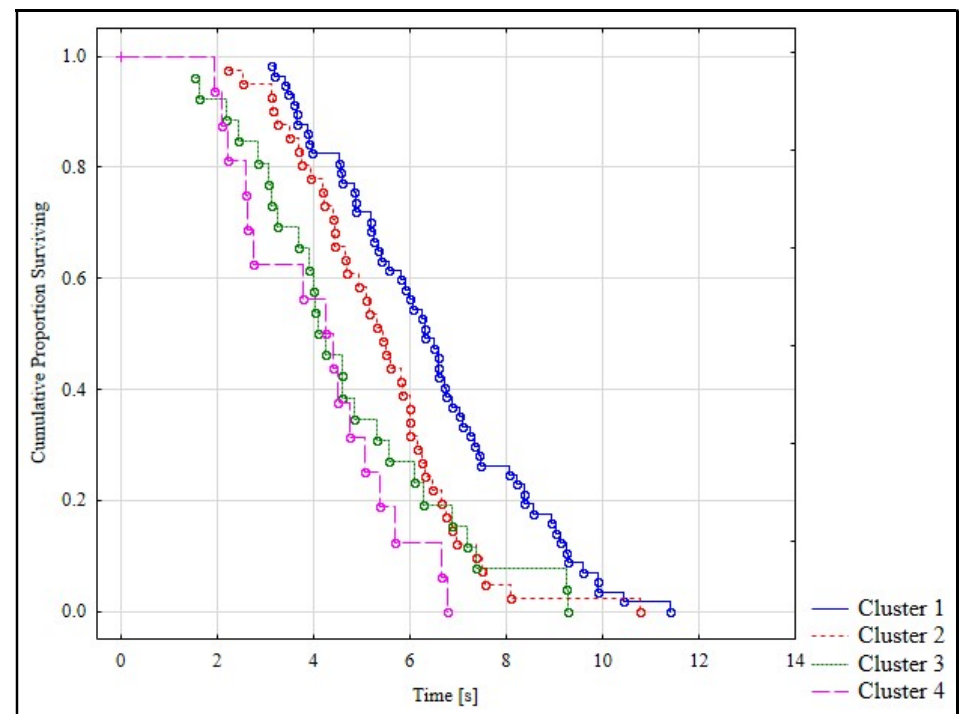

Figure 2. The obtained Kaplan-Meier surviving plot is generated by plotting the time on the $x$-axis and the proportion of those participants who made their decisions on the $y$-axis

\section{CONCLUSIONS}

In this study, leafy vegetables were evaluated which are used as component in salad mixes very often. Participants answered questions which were used to conduct value-based segmentation. The novelty of the experiment was that values and eye movement parameters were evaluated using the combination of different statistical methods (cluster analysis, survival analysis, Kruskal-Wallis and Dunn's pairwise comparison).

Decision times of the clusters created based on the values were used together with eye movement parameters for classification (based on their values, eye movement parameters, 
duration of decision making). Values describing the clusters were in accordance with eye movement parameters and with the time needed to make the final decison. Results are useful for package optimisation and selection of mixes contains for target groups (clusters) specially.

\section{ACKNOWLEDGEMENTS}

The authors would like to thank the participants for their help.

Supported by the ÚNKP-16-4 New National Excellence Program of the Ministry of Human Capacities.

\section{REFERENCES}

Ares, G., MAWAD, F., GiMÉnEZ, A., MAICHE, A. (2014): Influence of rational and intuitive thinking styles on food choice: Preliminary evidence from an eye-tracking study with yogurt labels. Food Quality and Preference 31: 28-37.

CARdello, A.V. (1998): Perception of food quality (Chapter 1). In: TAub, I. A., Singh, R. P. (eds). Food storage stability. CRC Press, Taylor \& Francis Group, Boca Raton, FL, USA. pp. 1-32.

GERE, A. (2016): Módszerfejlesztés a preferencia-térképezésben. Szent István Egyetem, doktori értekezés (http://www.doktori.hu/index.php? menuid=193\&vid=15760) pp. 68-71.

Gere, A., DANNER, L., NinO, de A., KovÁCs, S., DÜRRSCHMID, K., SiPOS, L. (2016): Visual attention accompanying food decision process: an alternative approach to choose the best models. Food Quality and Preference 51: 1-7.

HolmQvist, K., Nyströom, M., Andersson, R., van de Weijer, J. (2011): Eye tracking. A comprehensive guide to methods and measures. Oxford: Oxford University Press.

KeAst, R. S. J. (2010): Food quality perception (Chapter 3). In: ORTEGA-RIVAS E. (ed.). Processing effects on safety and quality of foods (Contemporary food Engineering Series, D.W. Sun series editor), CRC Press, Taylor \& Francis Group, Boca Raton, FL, USA. pp. 68-83.

Kovács E., Gere A., SzéKely D., KóKai Z., Sipos L. (2016): Eye-tracking tests in consumer perception of food. Journal of Food Investigation 62(2): 1062-1068.

Ragaert, P., Verbeke, W., Devlieghere, F., Debevere, J. (2004): Consumer perception and choice of minimally processed vegetables and packaged fruits. Food Quality and Preference 15(3): 259-270.

Tzia, C., Giannou, V., Lignou, S., Lebesi, D. (2016): Sensory evaluation of foods (Chapter 2). In: T. VARZAKAS and C. TZIA (eds). Handbook of Food Processing: Food Safety, Quality, and Manufacturing Processes. CRC Press, Taylor \& Francis Group, Boca Raton, FL, USA. pp. 41-71.

Verain, M. C. D., SiJTSEMA, S. J., ANTONIDES, G. (2016): Consumer segmentation based on food-category attribute importance: The relation with healthiness and sustainability perceptions. Food Quality and Preference 48: 99-106.

Zhou, T., Harrison, A. D., McKellar, R., Young, J. C., Odumeru, J., PiYasena P., Lu, X., MerCer, D. G., KARR, S. (2004): Determination of acceptability and shelf life of readyto-use lettuce by digital image analysis. Food Research International 37: 875-881. 